\title{
Pendidikan Jasmani Untuk Anak Usia Dini: Pengembangan Fundamental Movement Skill (FMS)pada Anak
}

\author{
Setiyo Utoyo ${ }^{1 凶}$, Yenti Juniarti ${ }^{2}$, Nurdiyah Sari ${ }^{3}$, Khairina Mangge ${ }^{4}$ \\ Pendidikan Guru Pendidikan Anak Usia Dini, Universitas Negeri Gorontalo \\ DOI: $\underline{10.31004 / \text { obsesi.v5i1.605 }}$
}

\begin{abstract}
Abstrak
Dalam penelitian ini tentunya memiliki tujuan yang akan dicapai setelah penelitian dilaksanakan, penelitian dengan mengangkat tema Pendidikan Jasmani Untuk Anak Usia Dini: Pengembangan Fundamental Movement Skill (FMS) bertujuan untuk membentuk fundamental skill pada anak usia dini agar dapat berkembang sesuai dengan karakter perkembangannya sehingga dapat menunjang aktivitasnya pada masa dewasa nanti. Penelitian ini menggunakan pendekatan penelitian dan pengembangan. Sedangkan model pengembangan yang digunakan adalah model pengembangan Research \& Development (R\&D) dari Borg dan Gall yang terdiri dari sepuluh langkah antara lain; 1) need asesmen 2) melakukan perencanaan 3) mengembangkan produk awal yang diuji oleh 3 ahli 4) melakukan uji lapangan kecil 5) revisi produk 6) melakukan uji coba lapangan sedang 7) revisi produk 8) uji coba lapangan besar 9) revisi produk 10) menyusun laporan penelitian. Hasil penelitian menunjukkan bahwa uji coba kelompok kecil memperoleh skor, $70.04 \%$, uji coba kelompok sedang 80, $34 \%$ dan uji coba kelompok besar 86.89\% sehingga efektivitas model untuk mengembangkan fundamental movement skill (FMS) pada anak bisa diterima dengan baik.
\end{abstract}

Kata Kunci: fundamental movement skill, jasmani, anak usia dini.

\begin{abstract}
In this study certainly has a goal that will be achieved after the research is carried out, research with the theme Physical Education for Early Childhood: Development of Fundamental Movement Skills (FMS) aims to form fundamental skills in early childhood so that they can develop in accordance with the character of their development so that they can support its activity in adulthood later. This study uses a research and development approach. While the development model used is the development model Research $\mathcal{E}$ Development (R\&D)of Borg and Gall which consists of ten steps including; 1) need assessment 2) planning 3) developing initial products tested by 3 experts 4) conducting small field tests 5) product revisions 6) conducting medium field trials 7) product revisions 8) large field trials 9) product revisions 10 ) compile research reports. The results showed that small group trials obtained scores, $70.04 \%$, medium group trials $80,34 \%$ and large group trials $86.89 \%$ so that the effectiveness of the model for developing fundamental movement skills (FMS) in children could be well received.
\end{abstract}

Keywords: Fundamental Movement Skills, Physical, Early Childhood

Copyright (c) 2020 Setiyo Utoyo, Yenti Juniarti, Gilang Ramadan

$\triangle$ Corresponding

Email Address : setiyo.utoyo@gmail.com (Griya Anisa B1 Jl. Taman Surya, Kelurahan Dembe II, Kecamatan Kota Utara, Kota Gorontalo)

Received 18 Juni 2020, Accepted tanggal 25 June 2020, Published 29 June 2020

404 | Jurnal Obsesi : Jurnal Pendidikan Anak Usia Dini, 5(1), 2021 


\section{PENDAHULUAN}

Keterampilan gerak yang dimiliki oleh seseorang tentu bukanlah terjadi dengan cara yang instan tanpa adanya proses yang baik, proses untuk menciptakan keterampilan gerak yang baik dapat dilakukan semenjak usia dini. Keterampilan gerak yang dimiliki oleh anak usia dini yang mereka pelajari khususnya di Raudatul Athfal akan membantu mereka dalam proses pembelajaran yang dilakukannya dimasa yang akan datang karena disetiap jenjang pendidikan yang dilewati oleh peserta didik akan semakin kompleks dan rumit gerakan yang dilakukannya. Abdelkarim, et al., (2017) menyatakan Physical activity (PA) sudah menjadi bagian yang sangat penting untuk proses perkembangan anak baik untuk meningkatkan kesehatan, kardiovaskuler dan sebagai sarana mereka untuk melakukan sosialisasi dengan teman sebayanya. Catherine, et al., (2015) menyatakan keterlibatan anakanak dalam setiap aktivitas fisik seperti berlari, menedang dan melompat pada masa kanakkanak akan membagun persepsi positif pada kompetisi olahraga yang akan bermuara pada peningkatan aktivitas fisik dan kebugaran jasmani pada level remaja (Barnett, et al., 2008). Khususnya pendidikan jasmani di Indonesia frekuensi dan ketepatan dalam proses pembelajaran keterampilan dasar merupakan sebuah masalah yang perlu mendapat perhatiaan khusus.

Dalam beberapa kasus pendidikan Raudatul Athfal di Indonesia, penyelenggaraan pendidikan Raudatul Athfal mememiliki beberapa keterbatasan dalam sumber daya manusia, guru dalam pendidikan Raudatul Athfal biasanya kurang dapat menerima pendidikan maupun pelatihan yang secara spesifik terhadap aktivitas fisik dan olahraga (Ardha et al., 2018). Hal ini yang membuat para guru tidak memiliki referensi yang cukup dalam menjalankan kelas pendidikan jasmaninya, namun hal ini juga menjadi sebuah masalah utama ketika kami mempertimbangkan anak usia dini secara khusus dan penuh kehati-hatian terhadap segala jenis kegiatan yang mereka lakukan agar dapat menghindari kerugian-kerugian yang diakibatkan dari aktivitas fisik dan latihan secara tidak wajar. Pada banyak kasus perbedaan gender menjadi sebuah permasalah yang cukup serius keterampilan gerak anak usia dini tidaklah sama antar anak laki-laki dan perempuan, kecenderungan anak perempuan lebih rendah terhadap penguasaan geraknya ketimbang anak laki-laki (Eather et al., 2018). Hal ini banyak terjadi dibeberapa Negara di asia tenggara seperti di Indonesia, dimana anak laki-laki lebih dominan terhadap penguasaan keterampilan dari pada anak perempuan (Hardy, et al., 2010).

Namun, merupakan sebuah kewajiban untuk memberikan pendidikan jasmani kepada anak usia dini agar tidak membedakan jenis kelamin dalam proses PA, karena hal tersebut akan dapat memberikan kesempatan bagi seluruh anak usia dini mengeskpresikan diri, membangkan minat, berlatih dan mengembangkan kemampuan mereka dengan beberapa jenis latihan fisik (Cohen, et al., 2014). Pada masa keemasan yang sedang dialami oleh anak usia dini merupakan sebuah modal yang amat penting bagi perkembanganya pada masa yang akan datang, khususnya pada keterampilan mengontrol objek yang baik (menedang, menangkap, melempar) dan keterampilan gerak (berlari, loncat, melompat) (Barnett, et al., 2009). Berdasarkan hasil observasi dilapangan pada RA Al Ishlah Kota Gorontalo, pada Desember 2019 lalu, bahwa adanya kesalahan-kesalahan gerak yang pada umumnya banyak dihasilkan dari proses pendidikan anak usia dini, dikarenakan ketidak pahaman pendidik terhadap proses pembelajaran pendidikan olahraga khususnya penyelenggaraan Raudatul Athfal itu sendiri.

Perlu diperhatikan bahwa proses PA seorang anak amat sangat perlu mendapat perhatian gerakkan dasarnya agar dalam mengikuti segala PA diberbagai cabang olahraga dapat dengan mudah menyesuaikan diri karena keterampilan motoriknya telah dipersiapkan dalam proses pembelajaran sejak seorang anak ada pada pendidikan Raudatul Athfal yang dilakukannya (Gallahue, \& Donnelly, 2007). Cabang olahraga atletik merupakan cabang olahraga yang menjadi dasar setiap gerakkan diberbagai cabang olahraga seperti bejalan, berlari, melompat, melempar dan sebagainya. Ini merupakan keterampilan motorik 
atau gerak dasar yang perlu dimiliki oleh setiap anak usia dini karena hal ini akan mejadi gerak dasar bagi seluruh cabang olahraga. Dalam beberapa kajian lain bahwa tingkat kebugaran seorang anak dipicu dengan keterampilan motorik yang buruk (Hands, 2008). Namun penelitian yang dilakukan adalah untuk mengetahui dampak dari buruknya keterampilan motorik terhadap tingkat kebugaran seorang anak, dalam kajian lainnya yang lebih sepesifik sangat pentingnya fundamental movement skill (FMS) tersebut dimiliki semenjak anak usia dini hal ini perlu memberikan kesempatan kepada anak-anak untuk dapat mengembangan FMS dan mempersiapkan untuk PA pada masa yang akan dating (Hardy et al., 2010). Penelitian ini menekankan bagaimana tentang penerapan FMS dapat diterapkan semenjak dini. Dan penelitian lainya bahwa dengan strategi yang tepat untuk mengembangkan keterampilan motorik pada usia dini amat penting guna membantu prilaku PA pada anak-anak serta mempertahankan prilaku PA mereka untuk masa yang akan datang (Loprinzi, Davis, \& Fu, 2015).

Penelitian ini menyimpulkan bagaimana penanaman PA pada anak-anak dapat memberikan dampak pada PA pada masa yang akan datang. Oleh karena itu, akan sangat penting untuk lebih mengarahkan pembahasan kepada pengembangan keterampilan motorik anak usia dini agar dapat lebih spesifik diarahkan kepada model FMS yang membuat proses pembelajaran menjadi lebih disenangi anak-anak, sehingga proses pemberian FMS bukan bersifat latihan dengan segala aturan yang membuat anak merasa terkekang dan bosen dengan aktivitas yang dilakukan. Dengan demikian, penelitian ini berusaha mengembangkan keterampilan motorik pada anak usia dini, dengan menyoroti pentingnya model pengembangan FMS untuk menyiapkan PA pada masa yang akan datang.

\section{METODE PENELITIAN}

Penelitian ini menggunakan pendekatan penelitian dan pengembangan. Sedangkan model pengembangan yang digunakan adalah model pengembangan Research $\mathcal{E}$ Development (R \& D) (Borg, \& Gall, 1983) yang terdiri dari sepuluh langkah antara lain: (1) Melakukan penelitian dan pengumpulan informasi (kajian pustaka, pengamatan subyek, persiapan laporan pokok persoalan) (2) Melakukan perencanaan (pendefinisian keterampilan, perumusan tujuan, penentuan urutan pengajaran, dan uji coba skala kecil) (3) Mengembangkan bentuk produk awal (penyiapan model latihan, penyusunan buku pegangan, dan perlengkapan evaluasi) (4) Melakukan uji lapangan permulaan (5) Melakukan revisi terhadap produk utama (sesuai dengan saran-saran dari hasil uji lapangan permulaan) (6) Melakukan uji lapangan utama. (7) Melakukan revisi produk (berdasarkan saran-saran dan hasil uji coba lapangan utama). (8) Uji lapangan (9) Revisi produk akhir (10) Membuat laporan dan mempublikasikan hasil penelitian.

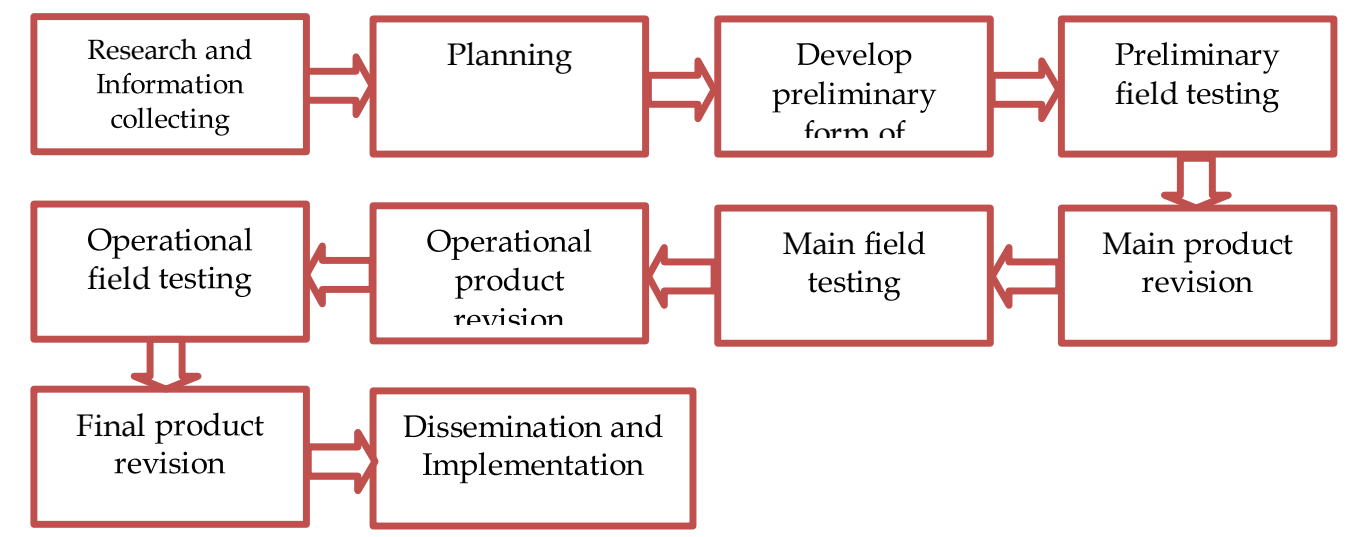

Gambar 1 Langkah-langkah penggunaan Metode Research and Development (R\&D) (Borg, \& Gall, 1983) 


\section{Langkah-langkah Riset Pengembangan}

Sumber Model FMS ini dikembangkan dengan menggunakan langkah pengembangan Borg\&Gall sebagai berikut ini adalah rancangan model pengembangan yang akan digunakan. Rancangan yang tergambar di atas adalah bentuk rancangan sesuai dengan langkah langan R\&D yang dilakukan oleh Borg dan Gall. Berikut: 1) Melakukan penelitian dan pengumpulan data untuk penelitian awal atau analisis kebutuhan (need assement). 2) Perencanaan pengembangan dilakukan dengan menentukan tujuan, membatasi ruang lingkup, dan mempersiapkan rencana uji coba. 3) Mengembangkan produk awal, yang selajutnya dievaluasi oleh 3 ahli pelatih dan melakukan revisi produk. 4) Uji coba kelompok kecil. 5) Revisi produk sesuai dengan hasil analisis pada uji coba kelompok kecil. 6) Uji coba lapangan (kelompok sedang). 7) Melakukan revisi produk sesuai hasil uji coba kelompok sedang. 8) Uji coba lapangan (kelompok besar). 9) Melakukan revisi tahap akhir sesuai dengam hasil analisis pada uji coba kelompok besar. 10) Membuat laporan hasil penelitian.

\section{Telaah Pakar (Expert Judgment)}

Tujuan dari evaluasi tahap pertama ini adalah untuk mengetahui kesesuaian model yang hendak diproduksi dan dikembangkan. Evaluasi tahap pertama terdiri dari: 1) Tinjauan dan analisa ahli, yang meliputi ahli perkembanga, ahli motorik anak usia dini yang. Untuk ahli pembelajaran pendidikan jasmani berfungsi memberikan informasi dan penilaian sumber belajar yang dikembangkan. Tinjauan para ahli yang terdiri dari 3 orang ahli, yaitu 2 orang ahli anak usia dini dan 1 orang ahli dosen ahli jasmanit. Kualifikasi ahli dalam pengembangan ini harus ditentukan dalam peranannya melakukan evaluasi atau revisi.

Uji validitas dilakukan dengan tujuan untuk mengetahui sejauh mana tes dapat mengukur dengan tepat aspek yang akan diukur. Berdasarkan hal ini maka uji validitas dari tes ini adalah dengan menggunakan uji validasi ahli, dimana instrumen yang telah disusun kemudian dikonsultasikan kepada para pakar.

Uji Coba Kelompok Kecil (Small Group Try-Out) dan Uji Coba Kelompok Sedang (Medium Group Try-Out)

Uji coba produk dilakukan untuk megumpulkan data yang digunakan sebagai dasar untuk menetapkan kelayakan produk yang dikembangkan peneliti. Tahap-tahap dalam uji coba produk ini antara lain: 1) menetapkan desain uji coba, 2) menetapkan subyek uji coba, 3) menetapkan jenis data, 4) menetapkan instrumen pengumpulan data, dan 5) teknik analisis data.

Pada tahap ini menggunakan subyek 15 guru-guru. Yang digunakan sebagai subyek pada tahap ini adalah guru-guru TK Damhil. Tujuan dari uji coba tahap I ini untuk mendapat masukan dengan jalan mengidentifikasi dan menyempurnakan produk yang dikembangkan setelah ditinjau oleh beberapa ahli. Langkah-langkah uji coba ini meliputi: a) Penjelasan tentang konsep produk kepada subyek (mahasiswa) b) Memberikan contoh pengembangan fundmental movement skill c) Meminta guru-guru untuk mencoba produk sesuai dengan yang dijelaskan d) Meminta guru-guru untuk memberikan tanggapan mengenai produk tersebut, melalui instrumen kuesioner.

Pada tahap ini juga akan di uji cobakan instrumen yang akan diberikan kepada para mahasiswa, dengan tujuan untuk mengetahui apakah instrumen yang telah dibuat peneliti sudah layak.

\section{Uji Coba Kelompok Sedang (Medium Group Try-Out)}

Pada uji coba sedang ini dilakukan setelah dilakukan perbaikan setelah melakukan uji coba pada kelompok kecil dan telah mengalami perbaikan sehingga dapat di ujikan kembali. Pada tahap ini jumlah subyek ditambah menjadi 30. Sementara tata cara pelaksananya sama seperti pada uji coba kelompok kecil. 


\section{Uji Coba Kelompok Besar (Field Try-Out)}

Pada tahap ini menggunakan subyek 50 mahasiswa. Yang digunakan sebagai subyek pada tahap ini adalah guru-guru TK Damhi. Tujuan dari uji coba tahap III ini untuk menjaga objektivitas produk yang dihasilkan serta untuk mengumpulkan berbagai informasi masukan sebagai dasar perbaikan dan penyempurnaan produk. Langkah-langkah uji coba ini meliputi: a) Penjelasan tentang konsep produk kepada subyek (mahasiswa). b) Memberikan contoh pengembangan fundmental movement skill. c) Meminta guru-guru untuk mencoba produk sesuai dengan yang dijelaskan. d) Meminta guru-guru untuk memberikan tanggapan mengenai produk tersebut, melalui instrumen kuesioner.

Pada tahap ini juga akan di uji cobakan instrumen yang akan diberikan kepada para guru-guru, dengan tujuan untuk mengetahui apakah instrumen yang telah dibuat peneliti sudah layak.

\section{HASIL DAN PEMBAHASAN}

\section{Hasil Analisis Kebutuhan}

Analisis kebutuhan dilaksanakan guna untuk melihat dan mengumpulkan informasiinformasi yang terjadi dilapangan terutama informasi terkait tentang pengembangan pendidikan jasmani. Kegiatan ini dilakukan dengan cara menganalisis dan mengamati kegiatan-kegiatan yang terjadi dilapangan, melakukan kajian literature. (Ramadan et al., 2020)

Adapun langkah dalam melakukan analisis kebutuhan dalam penelitian ini yaitu dengan cara menyebar angket analisis kebutuhan yang berupa pertanyaan-pertanyaan. Dengan tujuan untuk melihat sejauh mana subjek mengetahui tentang pengembangan FMS ini

Dibawah ini akan disajikan tabel analisis kebutuhan yang telah dilaksanakan pada 35 mahasiswa jurusan pendidikan guru pendidikan anak usia dini, adapun hasilnya adalah sebagai berikut:

Tabel 1. Data Hasil Analisis Kebutuhan

\begin{tabular}{|c|c|c|c|c|}
\hline \multirow[t]{7}{*}{$\mathrm{NO}$} & Item & Skor & $\begin{array}{l}\text { Skor } \\
\text { total }\end{array}$ & $\%$ \\
\hline & $\begin{array}{l}\text { 1.1. Apakah anda mendapatkan matakuliah Pengembangan } \\
\text { jasmani? }\end{array}$ & 35 & 35 & 100 \\
\hline & \multicolumn{4}{|c|}{ 1.2. Jika ya, dalam bentuk apakah pengajaran materi matakuliah tersebut? } \\
\hline & Teori & 35 & 35 & 100 \\
\hline & Praktik & 0 & 35 & 0 \\
\hline & Teori dan Praktik & 0 & 0 & 0 \\
\hline & $\begin{array}{l}\text { 1.3 apakah anda sudah menguasai materi Pengembangan } \\
\text { jasmani? }\end{array}$ & 15 & 35 & 49 \\
\hline \multirow[t]{9}{*}{2} & $\begin{array}{l}\text { 2.1. Apakah dalam pembelajaran Pengembangan jasmani } \\
\text { tersebut, dosen menggunakan berbagai media/sumber belajar } \\
\text { yang bervariasi? }\end{array}$ & 15 & 35 & 49 \\
\hline & \multicolumn{4}{|c|}{$\begin{array}{l}\text { 2.2. Bila menjawab Ya, apa saja bentuk Pengembangan jasmani yang tersedia? (bisa } \\
\text { memilih lebih dari satu alternatif jawaban) }\end{array}$} \\
\hline & Cetak & 35 & 35 & 100 \\
\hline & Powerpoint & 35 & 35 & 100 \\
\hline & Video & 15 & 35 & 48 \\
\hline & Praktek Langsung & 15 & 35 & 48 \\
\hline & Lainnya & 0 & 35 & 0 \\
\hline & $\begin{array}{l}\text { 2.3. Apakah dosen anda pernah menggunakan media } \\
\text { pembelajaran dalam bentuk permainan/praktek langsung? }\end{array}$ & 35 & 35 & 100 \\
\hline & 2.4. Jika jawaban anda pernah, sebutkan dalam bentuk apa? & 35 & 35 & 100 \\
\hline
\end{tabular}




\begin{tabular}{|c|c|c|c|c|}
\hline $\mathrm{NO}$ & Item & Skor & Skor & $\%$ \\
\hline \multirow[t]{11}{*}{3} & $\begin{array}{l}\text { 3.1 Apakah anda sering melakukan gerakan dasar setiap hari } \\
\text { ? }\end{array}$ & 17 & 35 & 50 \\
\hline & 3.2. gerakan seperti apakah yang dilakukan? & 17 & 35 & 50 \\
\hline & \multicolumn{4}{|l|}{ 3.3. Berapa seringkah anda melakukan gerakan tersebut? } \\
\hline & lebih dari 3 jam & 10 & 35 & 40 \\
\hline & kurang dari 5 jam & 22 & 35 & 65 \\
\hline & lainnya: tidak tahu & 3 & 35 & 4 \\
\hline & \multicolumn{4}{|c|}{$\begin{array}{l}\text { 3.4. aktivitas apa saja yang anda dalam sehari? (bisa memilih lebih dari satu alternatif } \\
\text { jawaban) }\end{array}$} \\
\hline & Nonton & 35 & 35 & 100 \\
\hline & Bermain & 25 & 35 & 55 \\
\hline & Belajar & 17 & 35 & 49 \\
\hline & lainnya: berjualan online & 2 & 35 & 3 \\
\hline \multirow[t]{3}{*}{4} & $\begin{array}{l}\text { 4.1 Apakah pengembangan fundamental movement skill ini } \\
\text { bisa dijadikan alat melatih gerak dasar anak? }\end{array}$ & 35 & 35 & 100 \\
\hline & $\begin{array}{l}\text { 4.2 Apakah perlu adanya pengembangan fundamental } \\
\text { movement skill dalam bentuk gerak dan panduan? }\end{array}$ & 35 & 35 & 100 \\
\hline & $\begin{array}{l}\text { 4.3. Akan ada pengembangan fundamental movement skill } \\
\text { dalam bentuk gerak dan panduan, apakah anda setuju dan } \\
\text { tertarik untuk menggunakannya? }\end{array}$ & 35 & 35 & 100 \\
\hline
\end{tabular}

Tabel analisis kebutuhan di atas menggambarkan bahwa ada beberapa point penting untukk dilaksanakannya pengembangan Fundamental Movemen Skill: pendidikan jasmani pada anak. Antara lain adalah, bahwa 1) dari 35 mahasiswa 100\% mahasiswa mendapatkan matakuliah pengembangan jasmani, 2) dari 35 mahasiswa 49\% mahasiswa masih belum menguasai materi pengembangan pendidikan jasmani, 3) dari 35 mahasiswa 49\% menyatakan bahwa dosen menggunakan berbagai media/sumber belajar yang bervariasi, 4) dari 35 mahasiswa 100\% mahasiswa pernah menggunakan media pembelajaran dalam bentuk permainan/praktek langsung, 5) dari 35 mahasiswa 50\% sependapat bahwa mahasiswa sering melakukan gerakan dasar setiap hari, 6) dari 35 mahasiswa 100\% setuju jika diadakan pengembangan FMS ini bisa dijadikan alat melatih gerak dasar anak, 7) dari 35 mahasiswa $100 \%$ menyatakan bahwa perlu adanya pengembangan FMS dalam bentuk gerak dan panduan. 8) dari 35 mahasiswa 100\% menyatakan bahwa perlu adanya pengembangan FMS dalam bentuk gerak dan panduan, apakah anda setuju dan tertarik untuk menggunakannya.

Selain menganalisis kebutuhan di lapangan,peneliti juga melakukan uji coba lapangan, yaitu uji coba lapangan kecil dan uji coba lapangan besar, dengan melibatkan ketiga ahli yaitu dua orang ahli paud dan satu orang ahli jasmani, yaitu sebagai berikut:

Tabel 2. Hasil Uji Coba Efektivitas Model di Lapangan

\begin{tabular}{ccc}
\hline Uji Coba & Skor $(\%)$ & Kreteria \\
\hline Uji coba lapangan kecil & 70.04 & Valid \\
Uji coba lapangan sedang & 80.34 & Valid \\
\hline Uji coba lapangan besar & 89.88 & valid \\
\hline
\end{tabular}

\section{Analisis Data Uji Coba Kelompok kecil}

Setelah produk model pengembangan fundamental movement skill: pendidikan jasmani pada anak usia dini melalui pendekatan permainan yang di uji cobakan oleh calon guru yaitu mahasiswa jurusan PG PAUD, direvisi sesuai dengan arahan pada pakar maka produk di uji cobakan dengan melibatkan mahasiswa yang berjumlah 35 mahasiswa.

Uji coba ini bertujuan untuk mengetahui dan mengidentifikasi berbagai kendala yang akan muncul seperti ketepatan media, metode, kelebihan dan kekurangan produk saat digunakan untuk pembelajaran yang diberi kuesioner kepada mahasiswa. Berdasarkan 
hasil analisis di dapat rata-rata pilihan sebesar 70,04\%. Berdasarkan kriteria yang telah ditentukan maka model latihan keseimbangan gerak di lingkungan halaman sekolah pada uji coba skala kecil masuk kategori baik

\section{Analisis Data Uji Coba Kelompok Sedang}

Setelah produk model pengembangan fundamental movement skill: pendidikan jasmani pada anak usia dini melalui pendekatan permainan pada mahasiswa jurusan PG PAUD, bulan januari lalu di uji cobakan pada uji coba kelompok kecil maka setelah uji coba kelompok kecil produk kembali direvisi sesuai dengan kondisi sebenarnya saat produk itu diuji cobakan kepada sampel dan juga meminta saran dan arahan kepada pakar maka produk di uji cobakan dengan melibatkan berjumlah 35 mahasiswa.

Berdasarkan hasil analisis didapat rata-rata pilihan sebesar $80,34 \%$. Berdasarkan kriteria yang telah ditentukan maka model latihan keseimbangan gerak di lingkungan halaman sekolah pada uji coba skala besar masuk kategori sangat baik.

\section{Analisis Data Uji Coba Kelompok Besar}

Setelah produk model model pengembangan fundamental movement skill: pendidikan jasmani pada anak usia dini melalui pendekatan permainan pada mhasiswa paud calon guru, di uji cobakan pada uji coba kelompok sedang maka setelah uji coba kelompok sedang maka produk akan kembali direvisi sesuai dengan kondisi sebenarnya saat produk itu diuji cobakan kepada sampel dan juga meminta saran kepada dan arahan pada pakar maka produk di uji cobakan dengan melibatkan mahasiswa yang berjumlah 35 anak.

Dalam melaksanakan pengembangan model latihan keseimbangan dimulai dengan skala kecil sampai dengan skala besar pelaksanaannya relatif sama hanya saja setelah melakukan uji coba akan diselingi oleh revisi produk hal ini untuk menyesuaikan produk yang dibuat dengan tanggapan penguna produk agar produk yang digunakan dapat digunakan dan dimanfaatkan dengan baik. Berikut adalah contoh permainan keseimbangan secara keseluruhan.

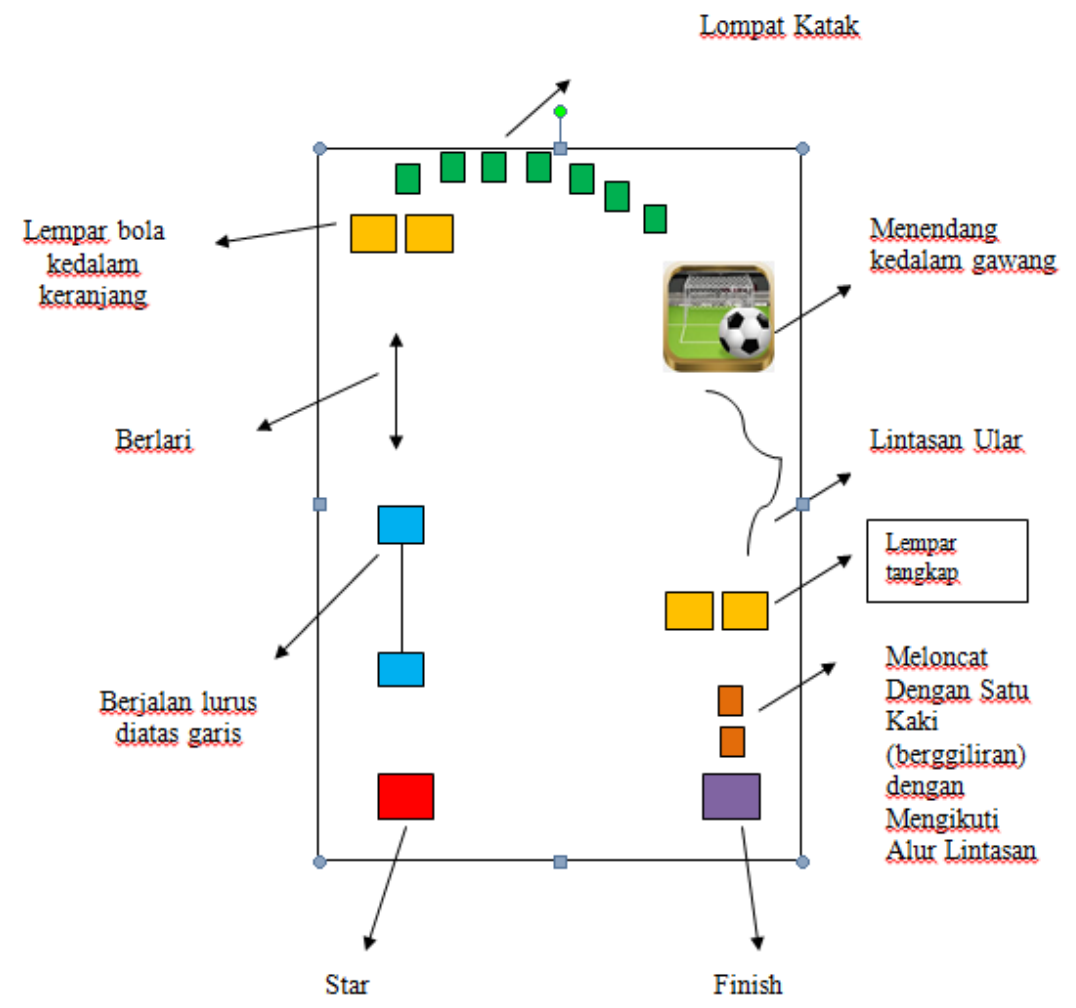

Gambar 1. Permainan Fundamental Movement Skill (FMS) 
Dari gambar di atas dapat diceritakan secara singkat proses permainan dalam rangka pengembangan Fundamental Movement Skill (FMS) dimana Anak disuruh berjalan lurus di atas garis sejauh 5 meter, jika tidak lurus maka kembali lagi ke awal, jika berhasil maka lanjut ke poin 2 lari sejauh 5 meter, di point ketiga anak harus melempar bola plastic ke dalam keranjang sebanyak 5 buah, setelah itu anak lompat katak sejauh 5 meter dan masuk ke poin selanjutnya menandang kedalam gawang. Anak berjalan mengikuti garis berliuk-liuk seerti uar, selanjutnya anak melakukan lempar tangkap dengan gurunya sebanyak 10 kali sambil berjalan miring, terus melompat dengan satu kaki tumpu dan bergantian kanan dan kiri dengan mengikuti alur lintasan sampai finish.

Berdasarkan hasil analisis didapat rata-rata pilihan sebesar $86,49 \%$. Berdasarkan kriteria yang telah ditentukan maka model latihan keseimbangan gerak di lingkungan halaman sekolah pada uji coba skala besar masuk kategori sangat baik.

Dengan adanya pengembangan FMS ini yang dikemas dalam bentuk permainan, sehingga ada beberapa temuan yang di dapat oleh peneliti, dimana temuan itu menyatakan bahwa setelah melaksanakan kegiatan ini anak merasa bahwa dengan melakukan aktvitas FMS yang dikemas dalam bentuk permainana membuat anak menjadi enjoy dan rilex, seperti yang kita ketahui bahwa bermain merupakan dunia yang tidak terpisahkan bagi anak dan memberikan makna yang begitu mendalam di memori si pelaku atau anak (Munawaroh, 2017), selain itu temuan yang di dapat adalah dimana anak merasa bahwa dengan bermain selain fisik motorik anak yang terasah juga anak mampu berkomunikasi serta bersosialisasi dengan temannya, seperti anak secara tidak sadar berbicara dan minta bantuan kepada temannya dalam melaksanakan aktivitas tersebut (Sari, Hartati, \& Yetti, 2019; Fika, Meilanie, \& Fridani, 2019)

Dari beberapa proses aktivitas pengembangan FMS yang dilakukan dengan bermaian, terlihat bahwa anak sangat menyukai gerakan-gerakan yang sifatnya ada unsur permainan sehingga anak dengan mudah melaksanakan aktivitas apapun dengan enjoy atau rilex dan juga anak bisa bersosialisai dan bercengkrama dengan teman sebayanya maupun dengan yang ada di sekitarnya.

Dalam proses pengembangan FMS ini peneliti tidak menguji sampai tingkat eksperimen untuk menguji dampak dari hasil FMS karena hal ini dikarenakan keterbatasan waktu penelitian sehingga pada pengembangan latihan fundamental movement skill ini difokuskan pada proses pembuatan produk latihan keseimbangan yang dituangkan pada buku latihan keseimbangan untuk anak taman kanak-kanak. Karena keseimbangan memiliki peranan penting dalam menujang performa seseorang sehingga sangat penting bagi seorang atlet sejak dini sudah memilki keeimbangan yang baik. Tentunya tugas ini tidak serta merta menjadi tanggung jawab pelatih saja tetapi juga menjadi tanggung jawab bersama agar dapat sama-sama memajukan olahraga tertutama di bidang pendidikan khususnya sekolah dasar memiliki peran yang sangat krusial dalam perkembangan tubuh anak-anak. Hal ini juga diperkuat oleh penelitian yang dilakukan oleh (Tauhidman \& Ramadan, 2018) Perkembangan Keseimbangan pada Anak Usia 7 s/d 12 Tahun Ditinjau dari Jenis Kelamin, bahwa keseimbangan menjadi hal yang sangat dibutuhkan sehingga perkembangan harus sangat diperhatikan sejak dini. Hal ini lah yang mendasari atau buah pikir pentingnya latihan keseimbangan karena penelitianpenelitian sebelumnya belum ada yang mencoba mengembangan model latihan keseimbangan.

\section{SIMPULAN}

Berdasarkan analisa hasil penelitian dan pembahasan dari produk awal sampai uji coba skala besar yang telah dilaksanakan oleh peneliti maka model latihan keseimbangan dapat digunakan dengan alasan sebagai berikut: 1) Produk model pembelajaran ini dapat diterima oleh anak didik berdasar hasi dari evaluasi ahli bidang olahraga dan ahli bidang motorik dengan nilai 80,34. 2) Secara keseluruhan 
pengembangan latihan kesimbangan sudah dapat digunakan dan dapat di sebar luaskan kepada masyarakat luas. 3) Model pembelajaran ini dapat diterima oleh siswa melihat dari angka analisis data yang mencapai $88,89 \%$ yang masuk dalam kategori baik sehingga model ini dapat digunakan.

\section{UCAPAN TERIMA KASIH}

Peneliti mengucapkan terimakasih kepada Universitas Negeri Gorontalo terutama Fakultas Ilmu Pendidikan yang telah memberikan kesempatan untuk peneliti bergabung pada penelitian kolaboratif FIP dengan mahasiswa sehingga peneliti bisa mengembangkan keilmuannya terutama di bidang pendidikan anak usia dini, peneliti juga mengucapkan terimakasih kepada jurusan dan mahasiswa yang terlibat dalam upaya pelaksanaan penelitian ini pada saat pengambilan data di lapangan.

\section{DAFTAR PUSTAKA}

Abdelkarim, O., Ammar, A., Chtourou, H., Wagner, M., Knisel, E., Hökelmann, A., \& Bös, K. (2017). Relationship between motor and cognitive learning abilities among primary school-aged children. Alexandria Journal of Medicine, 53(4), 325-331. https:// doi.org/10.1016/j.ajme.2016.12.004

Ardha, M. A. Al, Yang, C. B., Adhe, K. R., Khory, F. D., Harianto, T., \& Putra, K. P. (2018). Physical Education Curriculum for Early Childhood : Developing Students 'Manipulative Skill s in Soccer. 173(Icei 2017), 226-229.

Barnett, L. M., Morgan, P. J., van Beurden, E., \& Beard, J. R. (2008). Perceived sports competence mediates the relationship between childhood motor skill proficiency and adolescent physical activity and fitness: A longitudinal assessment. International Journal of Behavioral Nutrition and Physical Activity, 5, 1-12. https:/ / doi.org/10.1186/1479-5868-5-40

Barnett, L. M., van Beurden, E., Morgan, P. J., Brooks, L. O., \& Beard, J. R. (2009). Childhood Motor Skill Proficiency as a Predictor of Adolescent Physical Activity. Journal of Adolescent Health, 44(3), 252-259. https://doi.org/10.1016/j.jadohealth.2008.07.004

Borg, Walter R \& Gall, M. D. (1983). Educational Research (An introdu). White Plains, NY, England: Longman Publishing.

Capio, C. M., Sit, C. H. P., Eguia, K. F., Abernethy, B., \& Masters, R. S. W. (2015). Fundamental movement skills training to promote physical activity in children with and without disability: A pilot study. Journal of Sport and Health Science, 4(3), 235-243. https:// doi.org/10.1016/j.jshs.2014.08.001

Cohen, K. E., Morgan, P. J., Plotnikoff, R. C., Callister, R., \& Lubans, D. R. (2014). Fundamental movement skills and physical activity among children living in lowincome communities: A cross-sectional study. International Journal of Behavioral Nutrition and Physical Activity, 11(1). https://doi.org/10.1186/1479-5868-11-49

Eather, N., Bull, A., Young, M. D., Barnes, A. T., Pollock, E. R., \& Morgan, P. J. (2018). Fundamental movement skills: Where do girls fall short? A novel investigation of object-control skill execution in primary-school aged girls. Preventive Medicine Reports, 11(October 2017), 191-195. https:/ / doi.org/10.1016/j.pmedr.2018.06.005

Fika, Y., Meilanie, S. M., \& Fridani, L. (2019). Peningkatan Kemampuan Bicara Anak melalui Bermain Peran Berbasis Budaya. Jurnal Obsesi : Jurnal Pendidikan Anak Usia Dini. https:// doi.org/10.31004/obsesi.v4i1.229

Gallahue, D. L., \& Donnelly, F. C. (2007). Developmental Phsycal Education for All Childern. Human Kinetics Publishers.

Hands, B. (2008). Changes in motor skill and fitness measures among children with high and low motor competence: A five-year longitudinal study. Journal of Science and Medicine in Sport, 11(2), 155-162. https:/ / doi.org/10.1016/j.jsams.2007.02.012

Hardy, L. L., King, L., Farrell, L., Macniven, R., \& Howlett, S. (2010). Fundamental movement 
skills among Australian preschool children. Journal of Science and Medicine in Sport. https://doi.org/10.1016/j.jsams.2009.05.010

Loprinzi, P. D., Davis, R. E., \& Fu, Y. C. Early motor skill competence as a mediator of child and adult physical activity. , Preventive Medicine Reports § (2015). https://doi.org/10.1016/j.pmedr.2015.09.015.

Munawaroh, H. (2017). Pengembangan Model Pembelajaran dengan Permainan Tradisional Engklek Sebagai Sarana Stimulasi Perkembangan Anak Usia Dini. Jurnal Obsesi : Jurnal Pendidikan Anak Usia Dini, 1(2), 86. https:/ / doi.org/10.31004/obsesi.v1i2.19

Ramadan, G., Mulyana, N., Iskandar, D., Juniarti, Y., \& Hardiyanti, W. E. (2020). Physical Education for Early Childhood: The Development of Students' Motor in Athletics Basic Motion. https://doi.org/10.2991/ahsr.k.200214.023

Sari, C. R., Hartati, S. H., \& Yetti, E. (2019). Peningkatan Perilaku Sosial Anak melalui Permainan Tradisional Sumatera Barat. Jurnal Obsesi : Jurnal Pendidikan Anak Usia Dini. https:// doi.org/10.31004/obsesi.v3i2.225

Tauhidman, H., \& Ramadan, G. (2018). Pengembangan Model Latihan Keseimbangan untuk Sekolah Dasar. Jurnal SPORTIF : Jurnal Penelitian Pembelajaran. https://doi.org/10.29407/js_unpgri.v4i1.12012 